Article

\title{
Quartz Rb-Sr Isochron Ages of Two Type Orebodies from the Nibao Carlin-Type Gold Deposit, Guizhou, China
}

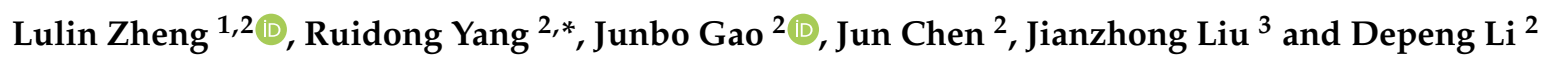 \\ 1 Mining College of Guizhou University, Guiyang 550025, China \\ 2 College of Resources and Environmental Engineering, Guizhou University, Guiyang 550025, China \\ 3 Geological Party 105, Guizhou Bureau of Geology and Mineral Exploration \& Development, \\ Guiyang 550018, China \\ * Correspondence: rdyang@gzu.edu.cn; Tel.: +86-851-8362-0551
}

Received: 3 May 2019; Accepted: 25 June 2019; Published: 28 June 2019

\begin{abstract}
The Nibao gold deposit, which includes both fault-controlled and strata-bound gold orebodies, constitutes an important part of the Yunnan-Guizhou-Guangxi "Golden Triangle" region. Defining the mineralization age of these gold orebodies may provide additional evidence for constraining the formation ages of low-temperature orebodies and their metallogenic distribution in South China. Petrographic studies of gold-bearing pyrites and ore-related quartz veins indicate that these pyrites coexist with quartz or filled in vein-like quartz, which suggests a possible genetic relationship between the two from Nibao gold deposit. Minerals chemistry shows that $\mathrm{Rb}$ and $\mathrm{Sr}$ are usually hosted in fluid inclusions in quartz ranging from 0.0786 to $2.0760 \mathrm{ppm}$ and 0.1703 to $2.1820 \mathrm{ppm}$, respectively. The $\mathrm{Rb}-\mathrm{Sr}$ isotopic composition of gold-bearing quartz-hosted fluid inclusions from the Nibao gold deposit were found to have Rb-Sr isochron ages of $142 \pm 3$ and $141 \pm 2$ Ma for both fault-controlled and strata-bound orebodies, respectively, adding more evidence to previous studies and thus revealing a regional gold mineralization age of 148-134 Ma. These results also confirm the Middle-Late Yanshanian mineralizing events of Carlin-type gold deposits in Yunnan, Guizhou, and Guangxi Provinces of Southwest China. In addition, previous studies indicated that antimony deposits in the region which were formed at ca. 148-126 Ma have a close affinity with gold deposits. This illustrates that the regional low-temperature hydrothermal gold mineralization is related in space and time to the Yanshanian (ca. 146-115 Ma) magmatic activity. Specifically, the large-scale gold and antimony mineralization are considered to be inherently related to mantle-derived mafic and ultramafic magmatic rocks associated with an extensional tectonic environment. Based on the initial ${ }^{87} \mathrm{Sr} /{ }^{86} \mathrm{Sr}$ ratios of $0.70844 \pm 0.00022(2 \sigma)$ and $0.70862 \pm 0.00020(2 \sigma)$ for gold-bearing quartz veins from fault-controlled and strata-bound gold orebodies, respectively, at the Nibao gold deposit, as well as the $\mathrm{C}, \mathrm{H}, \mathrm{O}$, and $\mathrm{S}$ isotopic characteristics of gold deposits located in the Golden Triangle region, we suggest that the mantle-derived material can be involved in the formation of the Nibao gold deposit and that the ore-forming fluid can be derived from a mixed crust-mantle source.
\end{abstract}

Keywords: mineralization age; Nibao gold deposit; ore-forming fluid; $\mathrm{Rb}-\mathrm{Sr}$ isotopic composition; Yunnan-Guizhou-Guangxi "Golden Triangle" region

\section{Introduction}

South China possesses a large region containing various types of low-temperature mineralization that produced many gold, antimony, mercury, thallium, and lead-zinc deposits. Southwestern Guizhou, adjacent to Yunnan and Guangxi Provinces in South China, is an important mining district for 
Carlin-type gold deposits, containing several large-scale gold deposits (e.g., Shuiyindong, Lannigou, Zimudang, Getang, etc.) (Figure 1).

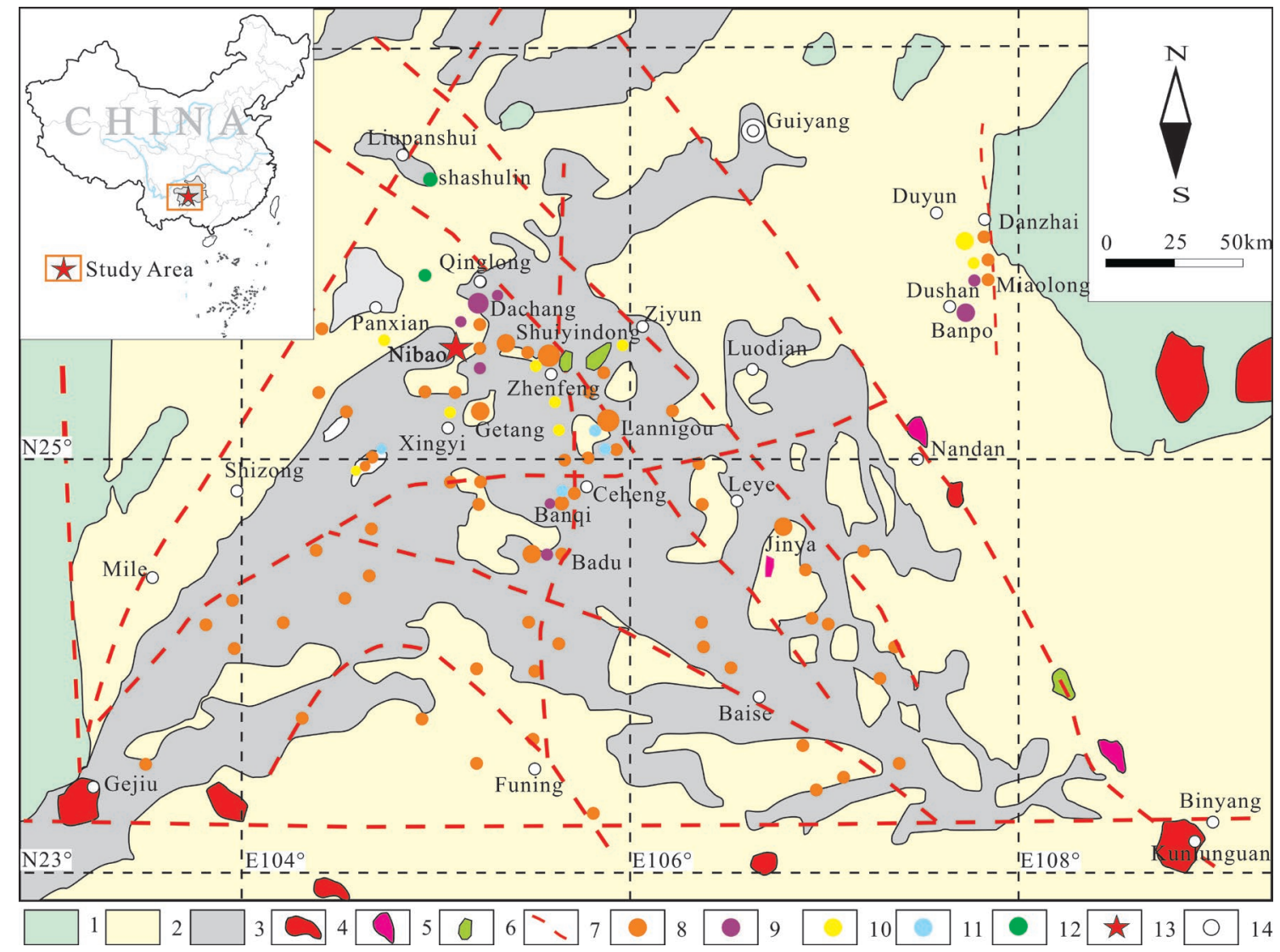

Figure 1. Geological map of low-temperature hydrothermal deposits distributed in the Yunnan-Guizhou-Guangxi "Golden Triangle" region: 1. Proterozoic; 2. Paleozoic; 3. Triassic; 4. Granite; 5. Quartz porphyry; 6. Alkaline mafic-ultramafic rock; 7. Fault; 8. Gold deposit; 9. Antimony deposit; 10. Mercury deposit; 11. Arsenic deposit; 12. Lead-zinc deposit; 13. Nibao gold deposit; 14. County town.

A strata-bound gold orebody was recently discovered at $1300 \mathrm{~m}$ below the surface in the Shuiyindong gold deposit, signifying a breakthrough in the bidimensional space prospecting in Guizhou Province. The orebody has a reserve of $263 \mathrm{tgold}$, with an average grade of approximately $5 \mathrm{~g} / \mathrm{t}[1]$, making the Shuiyindong a super-large gold deposit. The newly discovered Nibao gold deposit constitutes another large-scale deposit in Guizhou Province with gold reserves of $70 \mathrm{t}$ and the average grade of $2.6 \mathrm{~g} / \mathrm{t}$. Southwestern Guizhou presents extremely favorable metallogenic conditions for gold mineralization and shows a great potential for gold deposits. In addition to strata-bound gold orebodies, a large-scale fault-controlled orebody in the fault F1 has also been recently discovered in the Nibao deposit. This finding challenged the existing understanding of the Nibao gold deposit and showed that it can be not only a strata-bound-type deposits but also contains fault-controlled-type deposit [2]. Moreover, the large-scale gold deposits are mainly strata-bound or fault-controlled bodies in the Yunnan-Guizhou-Guangxi "Golden Triangle". For example, the Shuiyindong super-large gold deposit (263 t) belongs to a typical strata-bound deposit, where the orebodies occured mainly in the structure-controlled alteration zone (abbreviated as Sbt, according to its definition in Chinese) and the Longtan Formation. Whereas the Lannigou super-large gold deposit (110 $t$ ) occurred in the fault F3 and the Zimudang large gold deposit (72 t) occurred in the fault F1 are typical fault-controlled gold deposits. According to a comparison of the geological and geochemical characteristics of various typical Carlin-type gold deposits in the Yunnan-Guizhou-Guangxi Golden Triangle, it can be concluded that 
the Nibao gold deposit is not only unique but also general. Therefore, the Nibao gold deposit that is regarded as a representative Carlin-type gold deposit has a special and relatively high research value.

Some previous studies have focused on the genesis of the deposit, the source of ore-forming material, fluid evolution, and the metallogeny of the gold deposits in southwestern Guizhou, which have allowed a better understanding of their origin and evolution [3-13]. However, there is still considerable controversy with respect to a relatively large gold mineralization age interval (235-83 Ma) of gold deposits in this region, which makes it difficult to accurately determine the age of regional gold mineralization $[8,14-18]$. Defining the age of mineralizing events is considered to be the key to studying ore deposits and understanding the mechanism of ore formation and metallogeny. Therefore, in this study both the fault-controlled and strata-bound gold orebodies of the Nibao gold deposit were investigated in order to define the mineralization age by using the $\mathrm{Rb}-\mathrm{Sr}$ isochron dating method of fluid inclusions in quartz, and the quartz is considered to be closely associated with gold mineralization. Moreover, the age data should also constrain the metallogenic events involved in low-temperature mineralization in the Golden Triangle region of South China.

\section{Regional Setting and Geological Characteristics of Gold Deposits}

A few Carlin-type gold deposits in Southwest China were located in the Yunnan-Guizhou-Guangxi Golden Triangle, specifically in southeastern Yunnan, southwestern Guizhou, and northwestern Guangxi. The southwestern Guizhou region sits at the junction of the Yangtze Block and the western segment of the South China Fold Belt. Yanshanian (205-66 Ma) regional tectonism involved periods of extension and rifting along the block margins alternating with episodes of extrusive magmatism, which are considered to be important geological factors for regional gold mineralization. Hu et al. [4] noted that regional gold deposits occurred in strata from the Cambrian to Cretaceous periods but mainly in Permian and Triassic strata, where gold orebodies were controlled by the strata (referred to as the strata-bound type) or the faults (referred to as the fault-controlled type). Generally, the host rocks are mainly impure carbonates, sedimentary tuffs, tuffs in Permian and siltstones (or fine sandstones) in Triassic. The ore minerals are mainly pyrite, stibnite, arsenopyrite, realgar, orpiment and cinnabar, and gangue minerals are mainly quartz, calcite, dolomite, fluorite, illite, etc. More than 200 gold deposits showing have been discovered in the Golden Triangle, making it an important gold mining district of China.

The Nibao gold deposit is an important Carlin-type gold deposit located in Pu'an County in southwestern Guizhou. Tectonically, the deposit is situated at the transition zone between the Yangtze craton and the Youjiang orogenic belt (Figure 2a). The structure of the Nibao gold mining district is relatively simple and can be represented primarily by NEE-striking faults (F1-F4), the Erlongqiangbao anticline, and NW-striking faults (F6, F8, F10, and F11). The large-scale gold orebody mentioned above occurred mainly within fault F1 (Figure 2). The stratigraphy of the deposit mainly includes the Middle Permian Maokou Formation, the Upper Permian Longtan Formation, the Lower Triassic Yongningzhen Formation, and the Middle Triassic Guanling Formation. A structure-controlled alteration zone (abbreviated to Sbt, according to its definition in Chinese) was found in the ore-bearing strata. Here, Sbt refers to altered rocks which had been generated by Yanshanian regional structures (such as large-scale decollement structures) and had experienced hydrothermal alteration near the unconformity between the Maokou Formation (shallow platform carbonates) and the Longtan Formation. A more specific description of the structure-controlled alteration zone can be found in a previous study published by Zheng et al. [2]. Field investigations have revealed that the Longtan Formation, which can be divided into three members (the first, second, and third members of the Longtan Formation), mainly includes sedimentary tuffs, claystones with a minor amount of coal, limestones, and silicified limestones. The Yongningzhen Formation and the Guanling Formation consist mainly of sedimentary carbonates. Although there are no magmatic rocks exposed in the Nibao gold mining district, small-scale Late Yanshanian mafic, ultramafic, or intermediate medium-acidic igneous bodies were found to outcrop in the surrounding area (Figure 1). Moreover, Wang et al. [19] indicated that there may be underground 
basic-ultrabasic rock hide in the Nibao gold deposit by using geophysical exploration, the Emeishan basaltic Formation is distributed widely in the northwestern region near Panxian County (Figure 2b).

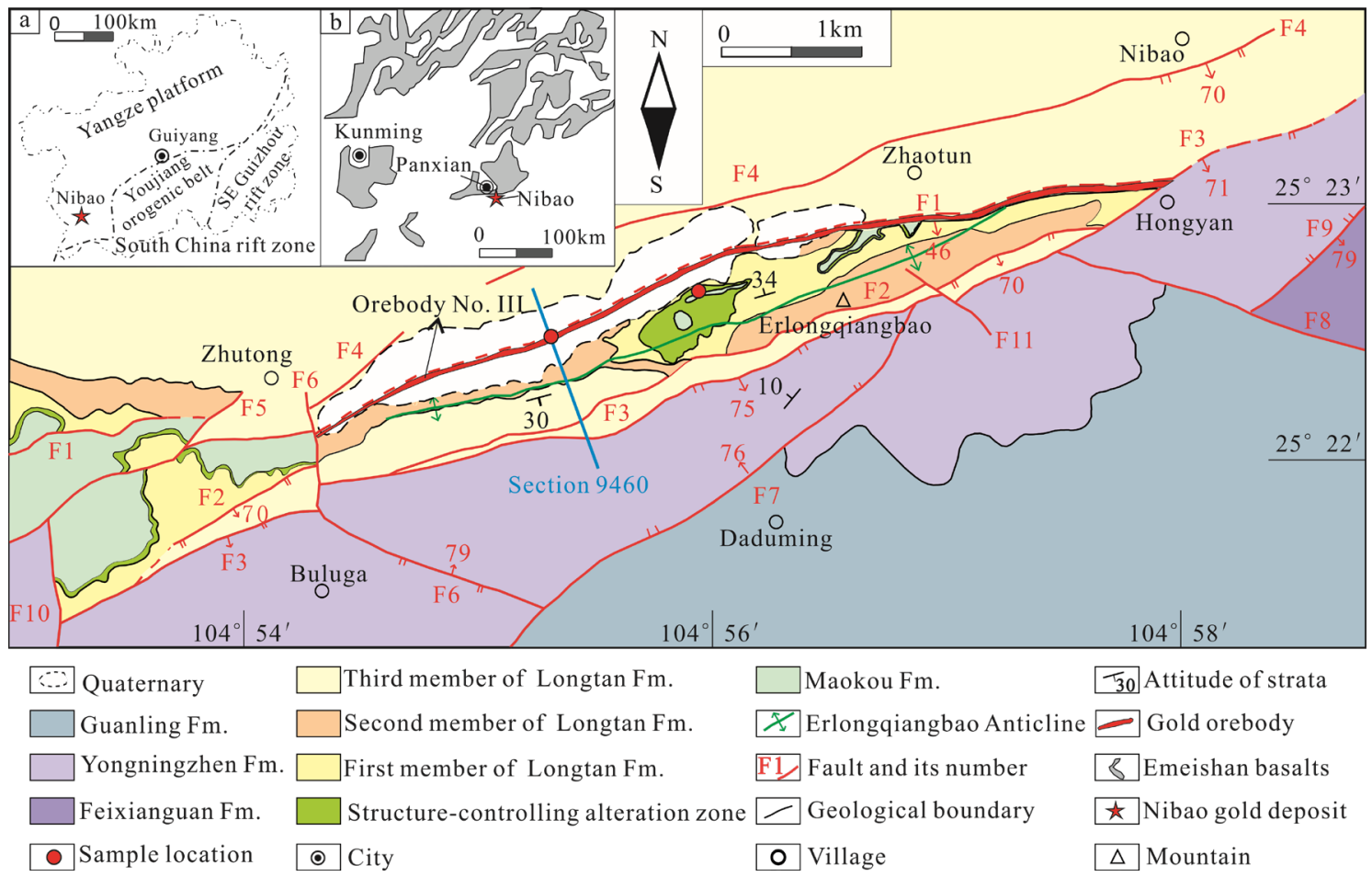

Figure 2. Geological map of Nibao gold deposit: (a) tectonic map and (b) geological map of the Emeishan basalt distribution (modified from He et al. [20]).

Most of the gold orebodies in the Nibao gold deposit were found in fault F1 or in the structure-controlled alteration zones, while the rest occurred in the first or the second member of the Longtan Formation (Figure 3). Gold orebodies in the Nibao gold deposit have been classified into fault-controlled and strata-bound types, and gold orebody No. III, which occurs as stratiform-like or lenticular layers, is of the fault-controlled type that is associated with fault F1. The orebody is $4084 \mathrm{~m}$ along strike, with a dipping extension of $540 \mathrm{~m}$, and presents an average thickness of $4.86 \mathrm{~m}$ and an average grade of $3.42 \mathrm{Au} \mathrm{g/t}$. The gold reserves reach $39 \mathrm{t}$, make it the largest orebody in the deposit. Strata-bound orebody No. IV occurs in the structure-controlled alteration zone unit, while layered orebodies No. I, II, and VI are in the Longtan Formation. Among these, orebody No. IV is a relatively large orebody in the Nibao mining district.

The gold ore is principally hosted by sedimentary tuffs (Figure $4 \mathrm{a}, \mathrm{c}-\mathrm{e}$ ) and tuffs (Figure $4 \mathrm{~b}, \mathrm{f}$ ), the $\mathrm{U}-\mathrm{Pb}$ zircon age of which is $251-263 \mathrm{Ma}$, as suggested by previous studies [20-23]. As revealed by this study, the gold mineralized rocks have been primarily affected by silicification (Figure $4 a, b, e, f)$ and pyritization (Figure 4a-f), and secondly by arsenopyritization (Figure 4c), while the host rocks underwent argillization (illitization) (Figure 4c,e,f) and carbonatization (calcitization and dolomitization) (Figure 4c-e). Gold mineralization occurs as the disseminated type in sedimentary tuffs (Figure 4) and as stockwork in tuffs (Figure 4b). Ore minerals (e.g., pyrite and arsenopyrite) contain most of the gold mineralization $[3,7,11,12]$. The gangue minerals include quartz, clay minerals (illite), dolomite, and calcite, among others. 


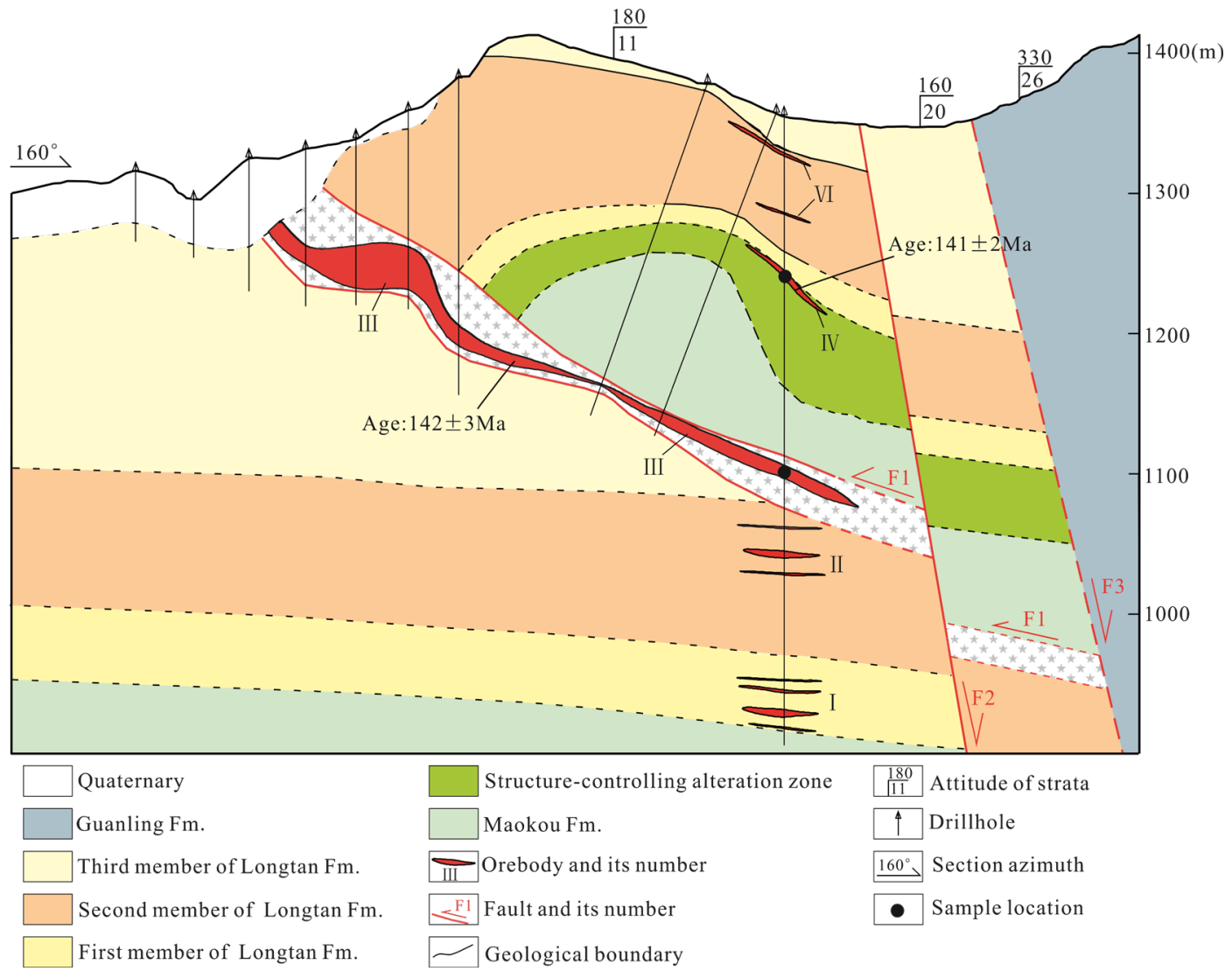

Figure 3. Cross section along the 9460 exploration line of the Nibao gold deposit.
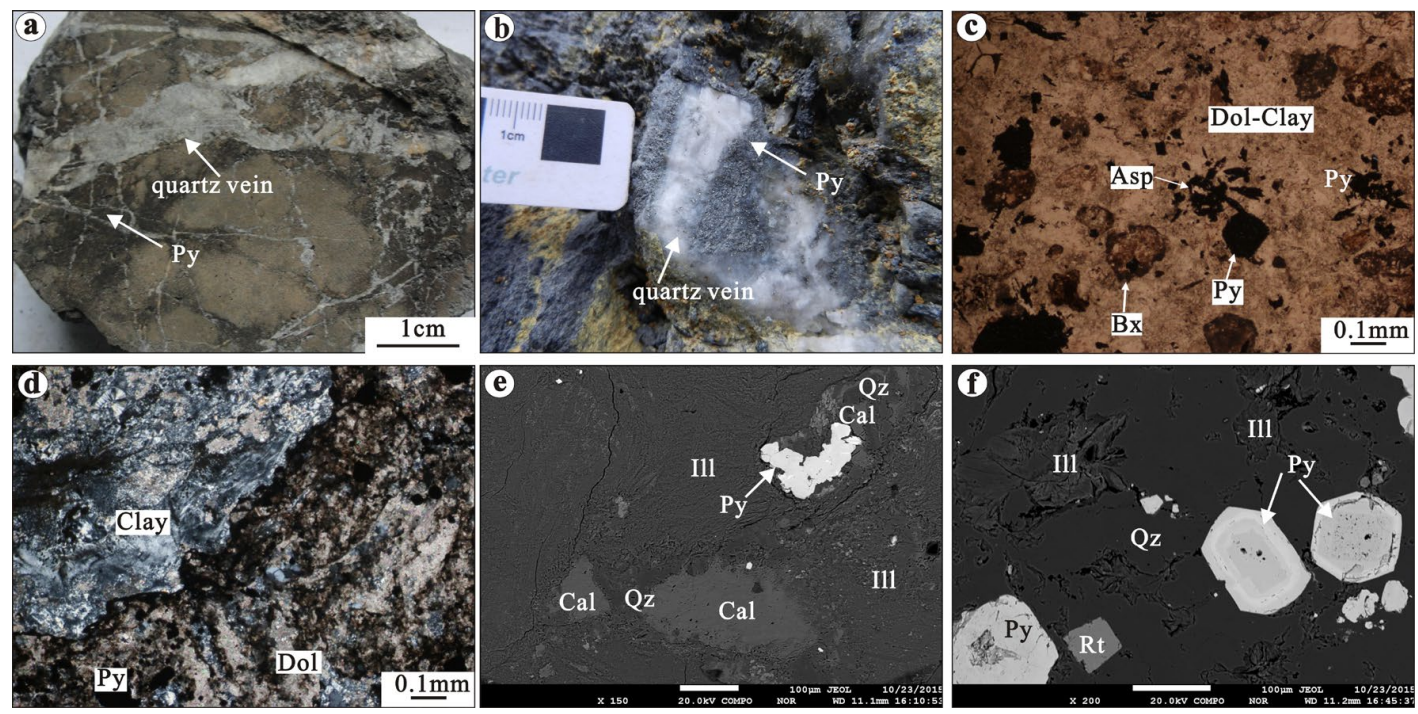

Figure 4. Macrocharacteristics and microscopic textures of various rocks in the Nibao gold deposit: (a) vein (stockwork) quartz and disseminated pyrite in sedimentary tuffs; (b) vein quartz associated closely with pyrite in tuffs; (c) pyrite showing subidiomorphic-idiomorphic granular texture and arsenopyrite showing subidiomorphic texture in sedimentary tuffs (transmitted light, polarized light); (d) strong argillization and carbonatization in sedimentary tuffs (transmitted light, crossed polarizers); (e) silicification, pyritization, carbonatization, and argillization in sedimentary tuffs (BSE); (f) silicification, pyritization, and argillization in tuffs (BSE). Mineral abbreviations: Py = pyrite, Asp $=$ arsenopyrite, $\mathrm{Dol}=$ dolomite, $\mathrm{Cal}=$ calcite, Clay $=$ clay, $\mathrm{Bx}=$ vitric tuff, $\mathrm{Rt}=$ rutile, $\mathrm{Qz}=$ quartz, Ill = illite. 
According to the ore texture characteristics and paragenesis of hydrothermal altered minerals, the Nibao gold deposit experienced three stages of formation: (1) the early quartz-pyrite stage, which involved layered quartz and quartz veinlets (stockwork) and pyrite characterized by banding or a low degree of euhedral granular texture; (2) the main stage of gold mineralization can be represented by a mineral assembly of quartz, arsenic-bearing pyrite, and arsenopyrite, in which the quartz occurred as stockwork, veinlets, and flecks along the joints and fissures. Further, there was a great amount of fine-grained disseminated pyrite and arsenic-rich pyrite showing zonal texture and arsenopyrite in angular, needle, and hair-like shapes; and (3) the later stage, when minerals such as quartz, carbonates, and clays (mostly illite) crystallized with quartz and calcite, often exhibiting a miarolitic texture.

\section{Sampling and Analytical Methods}

\subsection{Sampling}

Based on detailed field investigations of the characteristics of different orebodies (e.g., ore texture, rock alteration, etc.) in the Nibao gold deposit, a total of 10 ore samples associated with quartz veins were collected, of which 5 were collected from orebody No. III and the rest from orebody No. IV. It should be noted that samples from orebody No. III were collected from the cores of different drill holes in a shattered zone of fault F1. Quartz in these samples was mainly shaped as networks or strings, and occurred primarily in ore-bearing sedimentary tuffs (Figure 4a). Samples from orebody No. IV were all collected from an open-air profile of a structure-controlled alteration zone, the quartz of which mainly had a vein-like texture occurring in tuffs (Figure $4 b$ ). All the quartz was formed during gold mineralization and thus bore a close relationship with gold mineralization.

\subsection{Analytical Methods}

Clean quartz pieces were separated from samples by washing with distilled water, air-drying, and coarse crushing. The chosen quartz pieces were then finely crushed to less than $0.25 \mathrm{~mm}$ and cleaned by distilled water again. Finally, single mineral quartz grains were hand-picked under a binocular microscope, and the purity of the picked quartz was greater than $99 \%$.

Pretreatment and isotopic analysis of all quartz samples were completed in the Isotope Open Laboratory of the Wuhan Center, China Geological Survey. Sample preparation was conducted in an ultraclean laboratory. The $\mathrm{Rb}$ and $\mathrm{Sr}$ blanks for all of the isotopic analytical procedures were 0.0005 and $0.001 \mathrm{ppm}$, respectively, and a background correction for the $\mathrm{Rb}$ and $\mathrm{Sr}$ concentrations was implemented for all analyzed samples. The $\mathrm{Rb}-\mathrm{Sr}$ isotopic analysis involved the following steps: (1) Ultrapure hydrochloric acid, nitric acid, and pure water were used to clean the hand-picked quartz. (2) Cleaned quartz samples were placed in a drying oven and the temperature was between 120 to $180^{\circ} \mathrm{C}$ to decrepitate and thus remove secondary fluid inclusions. (3) The quartz was then washed three to five times in purified water in an ultrasonic cleaner and dried thoroughly. (4) An appropriate amount of quartz grains was weighed and mixed with ${ }^{85} \mathrm{Rb}+{ }^{84} \mathrm{Sr}$ mixing diluent. It was then dissolved in hydrofluoric and perchloric acids. After that, the $\mathrm{Rb}$ and $\mathrm{Sr}$ was liberated by a cationic resin (Dowex $50 \times 8$ ) exchange method. (5) The isotopic compositions of $\mathrm{Rb}$ and $\mathrm{Sr}$ were determined via a TRITON thermal ionization mass spectrometer (Thermo Fisher Scientific, Waltham, MA, USA). The isotopic dilution method (spiking) was employed to calculate the concentrations of $\mathrm{Rb}$ and $\mathrm{Sr}$ in the samples. During the analytical process, the ${ }^{87} \mathrm{Sr} /{ }^{86} \mathrm{Sr}$ isotopic compositions of certified reference materials (CRM) including NBS987, NBS607, and GBW04411 were determined to validate the accuracy and precision of the methodology. As a result, NBS987 gave an ${ }^{87} \mathrm{Sr} /{ }^{86} \mathrm{Sr}$ value of $0.71018 \pm 0.00006(2 \sigma)$; the ${ }^{87} \mathrm{Sr} /{ }^{86} \mathrm{Sr}$ ratio and $\mathrm{Rb}$ and Sr concentrations of NBS607 were $1.20037 \pm 0.00008(2 \sigma), 523.50 \mathrm{ppm}$, and $65.67 \mathrm{ppm}$, respectively; and the ${ }^{87} \mathrm{Sr} /{ }^{86} \mathrm{Sr}$ ratio and $\mathrm{Rb}$ and $\mathrm{Sr}$ concentrations of GBW04411 were $0.75985 \pm 0.00004$ $(2 \sigma), 249.10 \mathrm{ppm}$, and $158.50 \mathrm{ppm}$, respectively. The $\mathrm{Rb}$ and $\mathrm{Sr}$ concentrations and $\mathrm{Sr}$ isotopic ratios of these CRM within the error bound compared with the certified values. The least-squares method was applied to calculate the isochron age. 


\section{Analytical Results}

\subsection{Fluid Inclusion in Quartz}

Fluid inclusion petrography studies on main-stage quartz of strata-bound and fault-controlled bodies showed that there is seldom secondary fluid inclusions in quartz, and the primary fluid inclusions in quartz are quite abundant, most of them are scattered, isolated, or clustered, with a granularity of 4-12 $\mu \mathrm{m}$; and only a few of them are elongated, irregular, polygon, or negative crystallized (Figure 5). The fluid inclusions are mainly two-phase aqueous inclusions and a few of $\mathrm{CO}_{2}$-rich inclusions. Based on their components and phase behavior at room temperature $\left(20^{\circ} \mathrm{C}\right)$, three types of fluid inclusions including type I-two-phase aqueous inclusions (Figure 5), type II- $\mathrm{CO}_{2}-\mathrm{H}_{2} \mathrm{O}$ inclusions, and type III- $\mathrm{CO}_{2}$ inclusions are recognized. The homogenization temperature of fluid inclusions showed that the homogenization temperatures of strata-bound bodies are mainly between 220 and $280{ }^{\circ} \mathrm{C}$, average at $251{ }^{\circ} \mathrm{C}$ (Figure 6a), the salinity of which mainly ranged from 4 wt \% to $7 \mathrm{wt} \% \mathrm{NaCl}$ equivalent, average at $4.94 \mathrm{wt} \% \mathrm{NaCl}$ equivalent (Figure 6b), the ore-forming fluid density of which varied from 0.74 to $0.92 \mathrm{~g} / \mathrm{cm}^{3}$, average at $0.83 \mathrm{~g} / \mathrm{cm}^{3}$, and the vapor phase of two-phase aqueous inclusions mainly contains $\mathrm{CO}_{2}$ in addition to $\mathrm{CH}_{4}$ and $\mathrm{N}_{2}$ (the ore-forming fluid belongs to a $\mathrm{H}_{2} \mathrm{O}-\mathrm{NaCl}-\mathrm{CO}_{2}-\mathrm{CH}_{4}-\mathrm{N}_{2}$ system). In contrast, the homogenization temperatures of inclusions in fault-controlled bodies are mainly between 160 and $240{ }^{\circ} \mathrm{C}$, average at $231{ }^{\circ} \mathrm{C}$ (Figure $6 \mathrm{c}$ ), the salinity mainly of which ranged from $3 \mathrm{wt} \%$ to $5 \mathrm{wt} \% \mathrm{NaCl}$ equivalent, average at $4.75 \mathrm{wt} \%$ $\mathrm{NaCl}$ equivalent (Figure $6 \mathrm{~d}$ ), the ore-forming fluid density of which varied from 0.71 to $0.93 \mathrm{~g} / \mathrm{cm}^{3}$, average at $0.85 \mathrm{~g} / \mathrm{cm}^{3}$, and the vapor phase of two-phase aqueous inclusions contains $\mathrm{CO}_{2}$ in addition to $\mathrm{CH}_{4}$ or $\mathrm{N}_{2}$ (the ore-forming fluid belongs to a $\mathrm{H}_{2} \mathrm{O}-\mathrm{NaCl}-\mathrm{CO}_{2} \pm \mathrm{CH}_{4} \pm \mathrm{N}_{2}$ system).
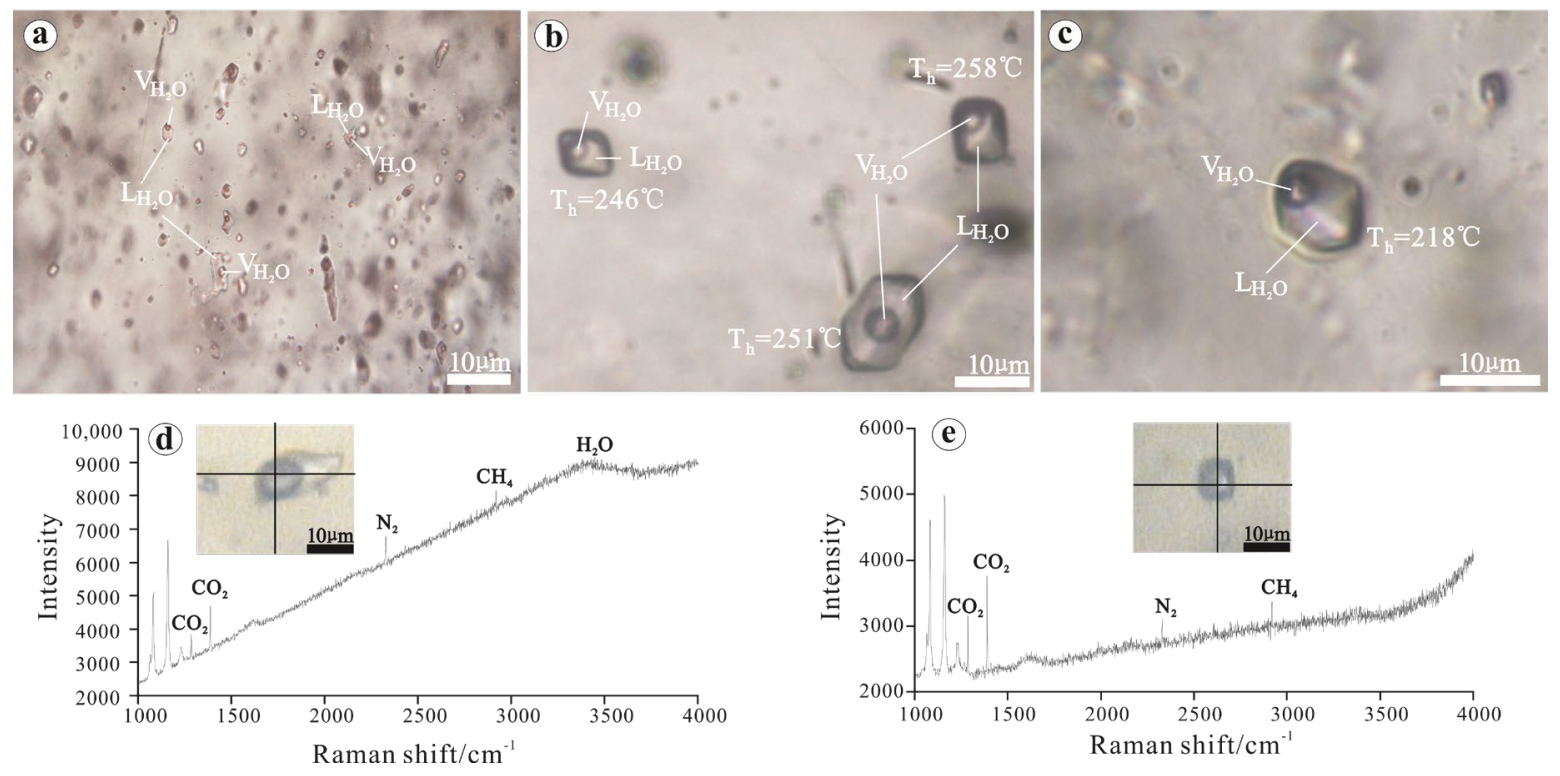

Figure 5. Microphotographs and laser Raman spectra of fluid inclusion in quartz from the Nibao gold deposit: (a,b) two-phase aqueous inclusions(main-stage quartz of Sbt); (c) two-phase aqueous inclusions (main-stage quartz of fault F1); (d) two-phase aqueous inclusions containing $\mathrm{CO}_{2}, \mathrm{~N}_{2}$, and $\mathrm{CH}_{4} ;(\mathbf{e}) \mathrm{CO}_{2}$ inclusions containing $\mathrm{N}_{2}$ and $\mathrm{CH}_{4}$. 

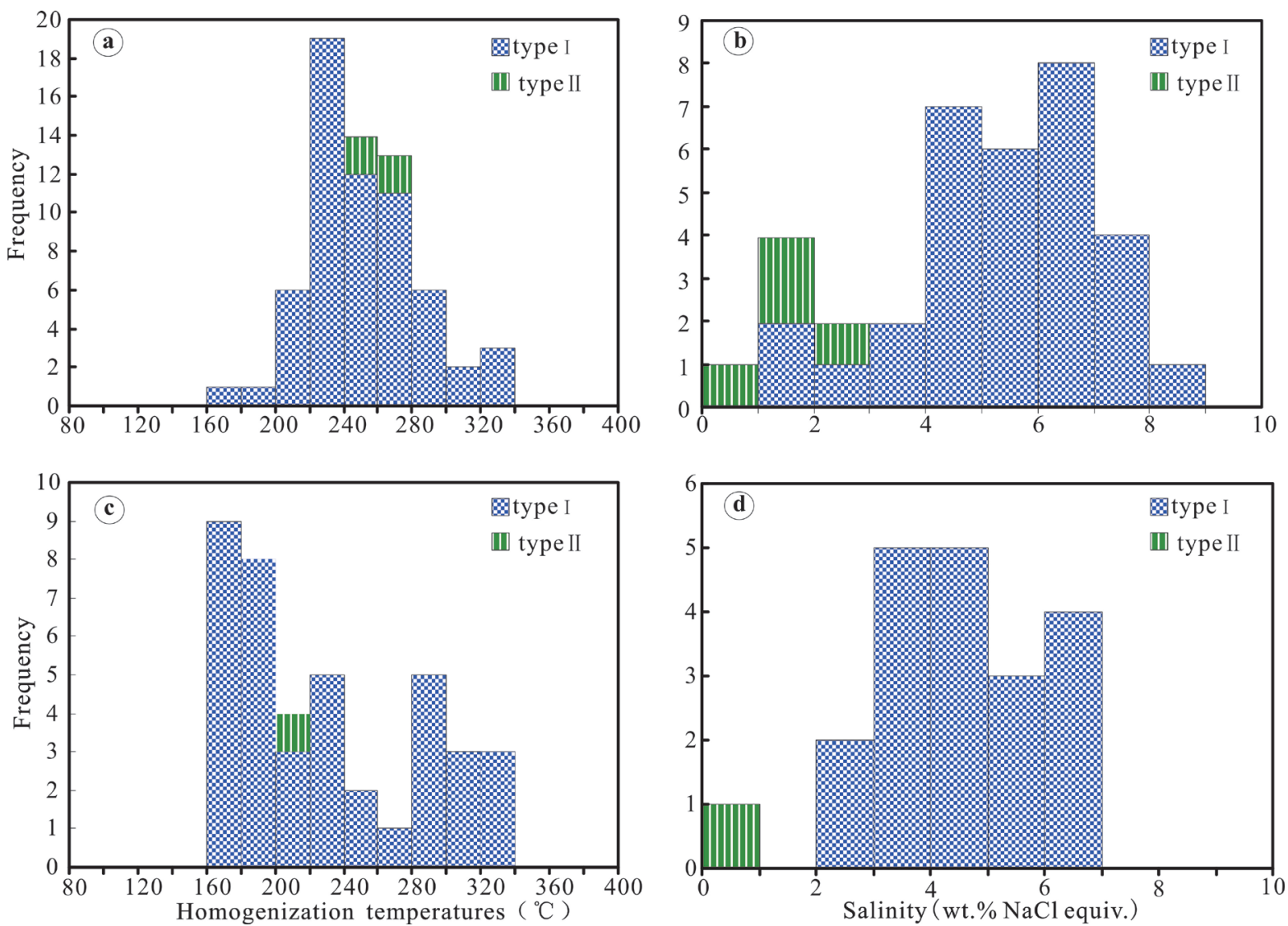

Figure 6. Histograms showing homogenization temperatures and salinities of fluid inclusions in two types of orebodies from the Nibao gold deposit: (a) histograms showing homogenization temperatures of fluid inclusions in the main-stage quartz of Sbt; (b) histograms showing salinities of fluid inclusions in the main-stage quartz of Sbt; (c) histograms showing homogenization temperatures of fluid inclusions in the main-stage quartz of fault F1; (d) histograms showing salinities of fluid inclusions in the main-stage quartz of fault F1.

\section{2. $\mathrm{Rb}-\mathrm{Sr}$ Isotopic Compositions}

The $\mathrm{Rb}-\mathrm{Sr}$ isotopic compositions of fluid inclusions in quartz collected from both the fault-controlled orebody No. III and the strata-bound orebody No. IV are presented in Table 1. For quartz from orebody No. III, the Rb content varied from 0.2921 to $2.0760 \mathrm{ppm}$, whereas the $\mathrm{Sr}$ concentration ranged from 0.6469 to $2.1820 \mathrm{ppm}$. Therefore, the obtained ${ }^{87} \mathrm{Rb} /{ }^{86} \mathrm{Sr}$ and ${ }^{87} \mathrm{Sr} /{ }^{86} \mathrm{Sr}$ ratios were 1.302 to 3.732 and $0.71103 \pm 0.00004$ to $0.71594 \pm 0.00004$, respectively. In the case of orebody No. $\mathrm{IV}$, the $\mathrm{Rb}$ concentration ranged from 0.0786 to $0.3333 \mathrm{ppm}$, while the Sr content varied from 0.1703 to $0.9890 \mathrm{ppm}$. Thus, the ${ }^{87} \mathrm{Rb} /{ }^{86} \mathrm{Sr}$ and ${ }^{87} \mathrm{Sr} /{ }^{86} \mathrm{Sr}$ ratios varied from 0.491 to 1.900 and $0.70961 \pm 0.00003$ to $0.71246 \pm 0.00004$, respectively. For these two types of gold orebodies, the variation range of the $\mathrm{Rb}$ and Sr isotopic data of fluid inclusions in quartz was relatively broad and was sufficient for constructing valid isochrons (Figure 7). The isochron ages of the fault-controlled gold orebody No. III and the strata-bound orebody No. IV were thus determined to be $142 \pm 3 \mathrm{Ma}(95 \%$ reliability) and $141 \pm 2 \mathrm{Ma}$ (95\% reliability), respectively. The isochron intercept gave the initial ${ }^{87} \mathrm{Sr} /{ }^{86} \mathrm{Sr}$ ratios of $0.70844 \pm 0.00022$ $(2 \sigma)(\mathrm{MSWD}=0.73)$ and $0.70862 \pm 0.00020(2 \sigma)(\mathrm{MSWD}=0.063)$, respectively. 
Table 1. The quartz fluid inclusion $\mathrm{Rb}-\mathrm{Sr}$ isotopic measurement results from the Nibao gold deposit.

\begin{tabular}{ccccccccc}
\hline Type & Position & Sequence No. & Lab. No. & Sample No. & $\mathbf{R b}(\mathbf{p p m})$ & $\mathbf{S r}(\mathbf{p p m})$ & ${ }^{87} \mathbf{R b} /{ }^{86} \mathbf{S r}$ & ${ }^{87} \mathbf{S r} /{ }^{86} \mathbf{S r} \pm \mathbf{2 \sigma}$ \\
\hline & & 1 & $3015648-1$ & $123-5$ & 1.0450 & 1.6960 & 1.776 & $0.71198 \pm 0.00005$ \\
fault-controlled & & 2 & $3015648-2$ & $543-5$ & 0.2921 & 0.6469 & 1.302 & $0.71103 \pm 0.00004$ \\
gold orebody No. III & fault F1 & 3 & $3015648-3$ & $9470-5-4$ & 1.0770 & 2.1820 & 1.423 & $0.71127 \pm 0.00001$ \\
& & 4 & $3015648-5$ & $544-4$ & 2.0760 & 1.6050 & 3.732 & $0.71594 \pm 0.00004$ \\
& & 5 & $3015648-6$ & $558-4$ & 0.9183 & 1.3770 & 1.923 & $0.71245 \pm 0.00005$ \\
\hline & & 1 & $3015647-1$ & NBP2-1 & 0.1197 & 0.7024 & 0.491 & $0.70961 \pm 0.00003$ \\
strata-bound & \multirow{2}{*}{ Sbt } & 2 & $3015647-2$ & NBP2-2 & 0.0786 & 0.1703 & 1.332 & $0.71126 \pm 0.00007$ \\
gold orebody No. IV & & 3 & $3015647-4$ & NBP2-4 & 0.1762 & 0.9890 & 0.514 & $0.70966 \pm 0.00004$ \\
& & 4 & $3015647-5$ & NBP2-5 & 0.3333 & 0.5059 & 1.900 & $0.71246 \pm 0.00004$ \\
& & 5 & $3015647-6$ & NBP2-6 & 0.1179 & 0.3465 & 0.981 & $0.71060 \pm 0.00004$ \\
\hline
\end{tabular}
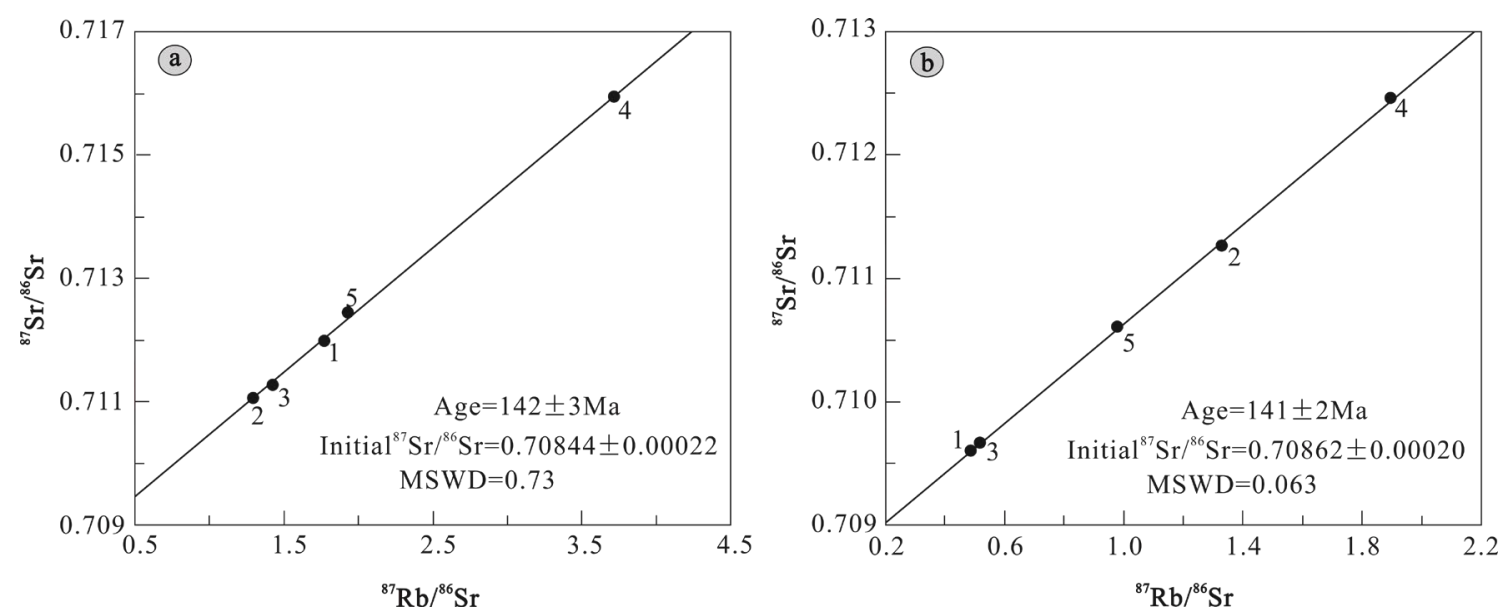

Figure 7. $\mathrm{Rb}$-Sr isotope isochronic ages of quartz from the Nibao gold deposit for (a) fault-controlled gold orebodies and (b) strata-bound gold orebodies. The numbers (1-5) are meaning the sequence No. in Table 1.

\section{Discussion}

\subsection{Age of Mineralization}

Because quartz is extremely pure and free of $\mathrm{Rb}$ - and Sr-rich impurities, $\mathrm{Rb}$ and $\mathrm{Sr}$ are usually hosted in fluid inclusions, quartz is an ideal target mineral for the $\mathrm{Rb}-\mathrm{Sr}$ dating method [24-28]. Therefore, the $\mathrm{Rb}-\mathrm{Sr}$ isochron method for fluid inclusions in quartz has been used as a tool to reveal the mineralization age of certain gold deposits [10,28-33].

Quartz samples for $\mathrm{Rb}-\mathrm{Sr}$ isotopic dating were all collected from the hydrothermal metallogenic stage that were related to gold mineralization. Five pieces of picked quartz samples were measured for gold content by the fire assay method and quantified by atomic absorption spectroscopy (Varian Spectr AA240) in ALS Chemex Co., Ltd. (Guangzhou, China). The results showed that the gold contents of these samples ranged from 0.106 to $3.640 \mathrm{ppm}$, indicating that the quartz samples were closely associated with gold mineralization. Therefore, we can conclude that the $\mathrm{Rb}-\mathrm{Sr}$ isochrons of fluid inclusions in quartz from the Nibao fault-controlled and strata-bound gold orebodies have ages of $142 \pm 3$ and $141 \pm 2 \mathrm{Ma}$, respectively, which are similar to each other within the error range. This also illustrated that these two types of orebodies were resulted from a single geological event.

Mao et al. [34] suggested that Mesozoic large-scale mineralization in South China may be related to the time taken for the lithosphere stretch in the same area. Specifically, Mesozoic mineralization occurred mainly around 170-150, 140-126, and 110-80 Ma, respectively, whereas the corresponding lithosphere stretch happened around 180-155, 145-125, and 110-75 Ma, respectively. The similarity between these values indicates that both of these events resulted from the same earth dynamic evolution, that is to say that the large-scale lithosphere stretch might have contributed to the massive mineralization. However, previous studies on the ore-forming ages of gold deposits in the Yunnan-Guizhou-Guangxi 
region show different results [14-16]. Age data greatly vary for different deposits due to using different dating methods, sometimes even within the same mining district (e.g., Lannigou and Shuiyindong) (Table 2), making the constraint of the mineralization age difficult. Another possible reason for this variation may be that the dating results provided by some determination methods cannot accurately represent the actual gold mineralization time. For example, since electron spin resonance spectroscopy is likely to be affected by epigenetic events, the age data are only valid before the time of the latest hydrothermal activity (i.e., the mineralization epoch's upper limit) [35]. Also, another study suggested that the accuracy of the Re-Os dating method is relatively due to the low content of arsenic pyrite, which is a target mineral for the measurement [36]. Moreover, the age of 235-193 Ma obtained by the Re-Os method is much older than those by other methods.

Table 2. The ages of typical gold deposits in the Golden Triangle region.

\begin{tabular}{|c|c|c|c|c|c|}
\hline Deposit & Stratum & Dating Methods & Dating Mineral & Ages (Ma) & Reference \\
\hline \multirow{2}{*}{ Nibao } & \multirow{2}{*}{ Permian } & SIMS Th-Pb age & Apatite & $142 \pm 3$ & [16] \\
\hline & & Fluid inclusion $\mathrm{Rb}-\mathrm{Sr}$ age & Quartz & $141 \pm 2 \sim 142 \pm 3$ & (This study) \\
\hline \multirow{3}{*}{ Lannigou } & \multirow{3}{*}{ Triassic } & Fluid inclusion $\mathrm{Rb}-\mathrm{Sr}$ age & Quartz, Calcite & 105.6 & [37] \\
\hline & & Quartz electron spin resonance (ESR) age & Quartz & $82.9 \pm 6.3$ & [35] \\
\hline & & Re-Os age & Arsenopyrite & $204 \pm 19$ & {$[15]$} \\
\hline \multirow{2}{*}{ Suiyindong } & \multirow{2}{*}{ Permian } & Sm-Nd age & Calcite & $134 \pm 3 \sim 136 \pm 3$ & [14] \\
\hline & & Re-Os age & Arsenopyrite & $235 \pm 33$ & {$[15]$} \\
\hline Zimudang & Permian & Sm-Nd age & Calcite & $148.4 \pm 4.8$ & {$[38]$} \\
\hline Baidi & Triassic & Quartz electron spin resonance (ESR) age & Quartz & $87.6 \pm 6.1$ & {$[35]$} \\
\hline \multirow{2}{*}{ Jinya } & \multirow{2}{*}{ Triassic } & Re-Os age & Arsenopyrite & $206 \pm 22$ & [15] \\
\hline & & SIMS Th-Pb age & Apatite & $146 \pm 6.2$ & [18] \\
\hline \multirow{2}{*}{ Badu } & \multirow[b]{2}{*}{ Permian } & SIMS U-Pb age & Rutile & $137.9 \pm 5.1$ & [18] \\
\hline & & SIMS U-Pb age & Zircon & $141 \pm 1.9$ & [18] \\
\hline
\end{tabular}

In contrast, the $\mathrm{Rb}-\mathrm{Sr}$ isotopic dating method for fluid inclusion in quartz and the $\mathrm{Sm}-\mathrm{Nd}$ isotopic dating method for fluid inclusion in calcite are appropriate choices for determining the age of gold deposits because of the data effectiveness and relatively small error bound [14,27]. This has been verified in a number of gold deposits in the study area. For example, the determined isotopic age of the Lannigou gold deposit was 105.6 Ma by the Rb-Sr method with fluid inclusions in quartz [37], the obtained isotopic age of the Shuiyindong gold deposit ranged from 134 $\pm 3-136 \pm 3$ Ma by the $\mathrm{Sm}-\mathrm{Nd}$ method with fluid inclusions in calcite [14], and the Sm-Nd method with fluid inclusions in calcite indicated that the achieved isotopic age of the Zimudang gold deposit was 148.4 $\pm 4.8 \mathrm{Ma}$ [38]

Notably, Chen et al. [16] used the SIMS U-Pb isochron method for hydrothermal apatite to date the age of the fault-controlled orebody in the Nibao gold deposit and obtained a result of $142 \pm 3 \mathrm{Ma}$, which is the same to the data in this study by the $\mathrm{Rb}-\mathrm{Sr}$ method with fluid inclusion in quartz. Generally, the gold deposits mentioned above are of the same mineralization age being of different ore-bearing strata and different structures. As shown in Figure 8, the mineralization age of the Carlin-type gold deposits in the Golden Triangle is mainly 148-134 Ma. This is consistent with the structural evolution background of the study area. After the Devonian period, the Golden Triangle experienced the following four stages of continental dynamics evolution: the Hercynian basin stretch-chasmic stage (405-250 Ma), the Indo-Chinese epoch arc-rear basin development stage (250-205 Ma), the Early-Medium Yanshanian intracontinental orogenic stage (205-140 Ma), and the Late Yanshanian postorogenic and crust stretch stage (140-66 Ma) [39]. The crust stretched during the Late Yanshanian stage and produced a great amount of ore-forming materials and fluids, thus developed massive medium-low temperature hydrothermal deposits in favorable host rocks or in some secondary structures over a large area. 


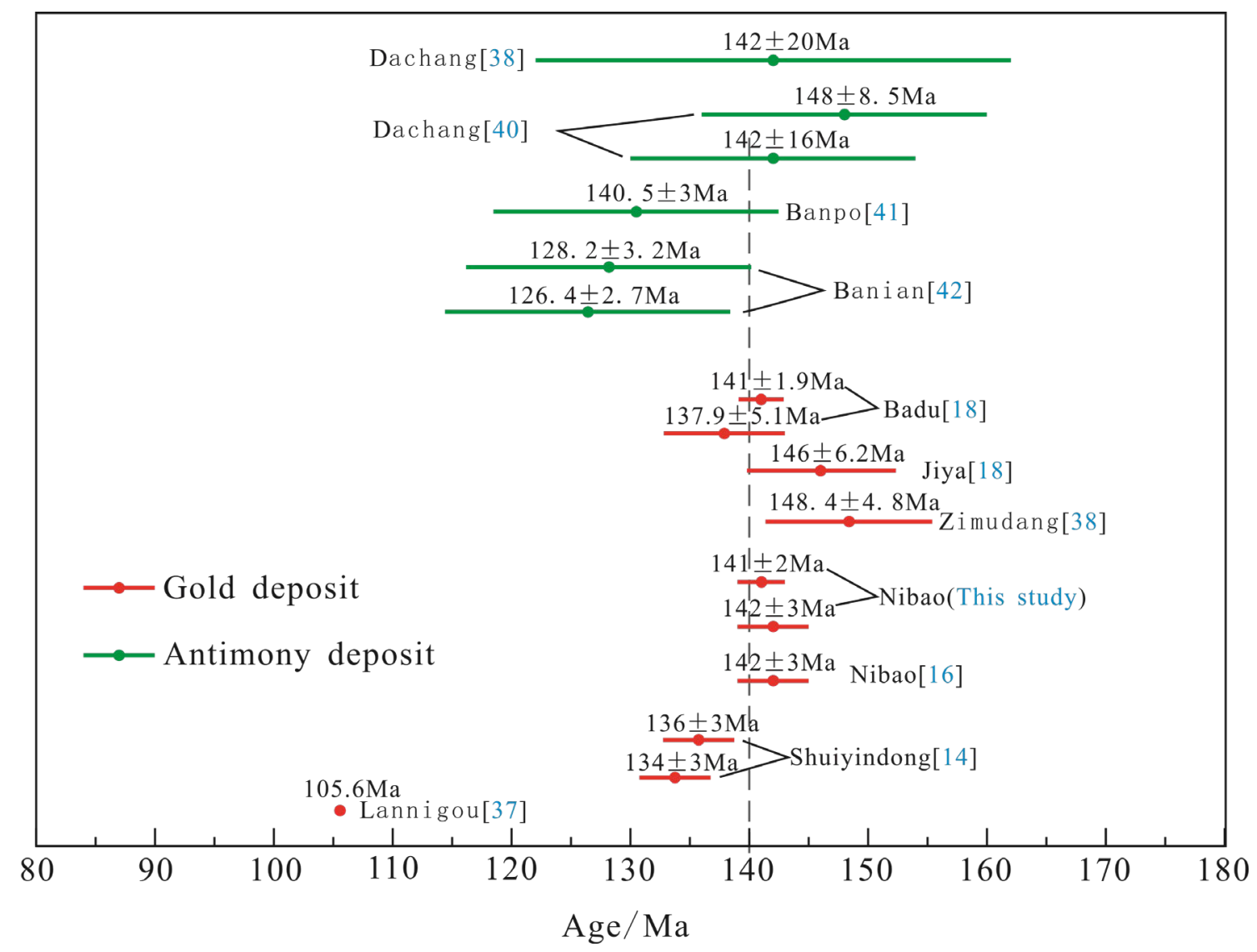

Figure 8. Mineralization ages of the gold and antimony deposits in the Yunnan-Guizhou-Guangxi Golden triangle region.

Furthermore, antimony deposits that are considered to be closely related to the gold deposits in the study area are of the mineralization age 148-126 Ma. For example, the fluorite $\mathrm{Sm}-\mathrm{Nd}$ isochron ages of the Dachang antimony deposit in Qinglong County varied 142 $\pm 16-148 \pm 8.5 \mathrm{Ma}$ [40] and $141 \pm 20 \mathrm{Ma}$ [38]. Moreover, the calcite Sm-Nd isochron age of the Banpo antimony deposit is $130.5 \pm 3.0 \mathrm{Ma}$ [41], and the calcite Sm-Nd isochron age of the Banian deposit in the Dushan antimony ore field is $126.4 \pm 2.7$ to $128.2 \pm 3.2 \mathrm{Ma}$ [42]. Since the isochron ages of two types of orebody from the Nibao gold deposit are close to each other, we concluded that the gold and antimony deposits in the study area might have been formed around $140 \mathrm{Ma}$ (i.e., in the same mineralization epoch, Middle-Late Yanshanian). This implies that both the gold and the antimony deposits were resulted from the same geological event, showing the differences only in the occurrence space, ore-bearing rocks, physicochemical conditions, fluid migration, and evolution time during the mineralization process.

Investigating the cross-cutting relationship between rock masses and orebodies is still considered to be an effective tool in terms of mineralization age research. It is actually a foundation for dating deposits when used with high-precision age determination. For example, the Shijia gold deposit located in northwestern Guangxi occurs not only in a fault-shattered zone within a diabase dyke but also at the contact zone between the diabase and the Carboniferous strata. Thus, the age of the diabase can provide the lower limit of the deposition age of the Shijia gold deposit, which is $<140 \mathrm{Ma}$ [43]. The muscovite ${ }^{40} \mathrm{Ar} /{ }^{39} \mathrm{Ar}$ method applied to quartz porphyry bodies located at Bama, Fengshan, Lingyun, and Liaotun in northwestern Guangxi yielded ages of 96.5-95.0 Ma. The contact relations between the porphyry and the gold deposit (Liaotun gold deposit) indicate that the latter age (95.0 Ma) represents the upper limit of the age of the gold deposit [36]. Therefore, from this perspective, it can be concluded that the mineralization of the Carlin-type gold deposits in the Yunnan-Guizhou-Guangxi Golden Triangle took place possibly around $140-95 \mathrm{Ma}$, which is basically the same as 148-134 Ma, which was 
obtained from the quartz $\mathrm{Rb}-\mathrm{Sr}$ method and the calcite $\mathrm{Sm}-\mathrm{Nd}$ method. Previous studies have shown that Mesozoic massive mineralization in South China may be related to lithosphere stretching and synchronal igneous intrusion activity; that is, there seems to exist a time-space catenation relationship between the two [4,34].

Whole-rock K-Ar isotopic analyses of intrusive rocks have yielded geochronological data that have reference value, such as the 146-115.5 Ma of diabase dykes from Pu'an and Panxian Counties [44]. Furthermore, Hu et al. [43] determined the age of the Shijia gold deposit and Badu diabase from northwest Guangxi to be 140 Ma by using the K-Ar isotopic method. Therefore, all the studies mentioned above suggest that the time of magmatic emplacement is almost the same as that of the mineralization of gold deposits (148-134 Ma) within the area of the Golden Triangle. This illustrates that the low-temperature hydrothermal deposit (i.e., gold deposit) in this area has a very close time and space relationship with Yanshanian magmatic activities. Thus, the massive gold and antimony mineralization could be attributed to late Yanshanian mantle-derived mafic-ultramafic magmatic activities that produced a stretching-structure environment.

In summary, based on the isotopic ages of two types of orebody from the Nibao gold deposit and the previous age data, we suggest that in the Yunnan-Guizhou-Guangxi Golden Triangle, the massive mineralization of low-temperature deposits represented by gold and antimony took place around $140 \mathrm{Ma}$.

\subsection{Ore-Forming Fluids}

Zheng et al. [1] studied the geochemical characteristics of gold orebodies hosted by different ore-bearing rocks in the Nibao gold deposit and found that all the orebodies possess a similar ore-forming source which had been mixed significantly by mantle-derived materials. It had been previously reported that the precipitation of quartz in a hydrothermal deposit has little influence on the $\mathrm{Sr}$ isotopic composition of the entire hydrothermal system, and thus, the ${ }^{87} \mathrm{Sr} /{ }^{86} \mathrm{Sr}$ ratio of fluid inclusions in quartz can reflect the properties of the ore-forming fluids $[25,45]$. Since quartz is closely associated with Carlin-type gold mineralization, variations of the $\mathrm{Sr}$ isotopic composition can provide indications for the ore-forming fluids and materials.

In the Nibao gold deposit, the initial ${ }^{87} \mathrm{Sr} /{ }^{86} \mathrm{Sr}$ ratios of fault-controlled and strata-bound gold orebodies are $0.70844 \pm 0.00022(2 \sigma)$ and $0.70862 \pm 0.00020(2 \sigma)$, respectively, which are distinctly lower than that of the average of the upper crust (0.71190) suggested by Palmer et al. [46], but are close to the original value of Sr (0.707) of the crust-mantle boundary reported by Faure [47]. Therefore, we can infer that ore-forming fluids possess characteristics of both mantle-derived $\mathrm{Sr}$ isotopes and stratigraphic Sr isotopes, suggesting that the $\mathrm{Sr}$ of the Nibao gold deposit may be of mixed origin. In addition, investigations of stable isotopes $(\mathrm{C}, \mathrm{H}$, and $\mathrm{O})$ and in situ sulfur isotopes of the gold deposits in southwestern Guizhou also suggest that the mineralization may involve mantle-derived material. Especially, the studies on $\mathrm{H}$ and $\mathrm{O}$ isotopes of several gold deposits (e.g., Yata, Banqi, Getang, Shuiyindong, Taipingdong, and Nibao) all showed that the ore-forming fluid may be a thermal fluid with multiple origins, namely, deep magmatic water mixed with meteoric water that migrated at shallower levels. This illustrates that there may be deeply covered rock masses underground $[4,8,10,13,48]$.

\section{Conclusions}

The Nibao gold deposit is an important part of the Yunnan-Guizhou-Guangxi Golden Triangle region. In this work, we investigated the mineralization ages of fault-controlled and strata-bound gold orebodies within the Nibao gold deposit. The key findings of this study are summarized below.

(1) $\mathrm{Rb}-\mathrm{Sr}$ isochron ages of $142 \pm 3$ and $141 \pm 2$ Ma were obtained from gold-bearing quartz vein fluid inclusions for the fault-controlled and strata-bound orebodies within the Nibao gold deposit. Since the regional age of gold mineralization varied from 148 to $134 \mathrm{Ma}$, we confirmed that the age of the Carlin-type gold deposits in the Golden Triangle is Middle-Late Yanshanian. 
(2) In the Nibao gold deposit, the initial ${ }^{87} \mathrm{Sr} /{ }^{86} \mathrm{Sr}$ ratios of fluid inclusions in gold-bearing quartz for fault-controlled and strata-bound gold orebodies are $0.70844 \pm 0.00022(2 \sigma)$ and $0.70862 \pm 0.00020$ $(2 \sigma)$, respectively. Considering the isotopic data and previously reported isotopic results $(\mathrm{C}, \mathrm{H}, \mathrm{O}$, and S) for gold deposits in this region, we infer that the mantle-derived material can be involved in the formation of gold deposits and that the ore-forming fluid was likely a mixture of crustal and mantle-derived fluids.

(3) In South China, low-temperature gold hydrothermal deposits are spatially and temporally related to Yanshanian magmatism, suggesting that large-scale gold mineralization has geneticity with Late Yanshanian mantle-derived mafic-ultramafic magmas.

Author Contributions: Conceptualization, R.Y. and L.Z.; methodology, R.Y. and L.Z.; software, L.Z. and D.L.; formal analysis, L.Z. and J.G.; investigation, L.Z., J.G., J.C. and D.L.; resources, R.Y. and J.L.; data curation, L.Z.; writing-original draft preparation, L.Z.; writing—review and editing, L.Z., R.Y., J.G., J.C. and J.L.; supervision, R.Y.; funding acquisition, R.Y.

Funding: This research was supported by the Talent introduction research project of Guizhou University (No. [2017]36), the National Natural Science Foundation of China (No. U1812402,41802088), the National Key Research and Development Program of China (No. 2017YFC0601500) and the Project of the Scientific and Technological Innovation Team of Sedimentary Deposit in Guizhou Province (2018-5613).

Acknowledgments: We sincerely appreciate the editors' and anonymous reviewer's comments. And thanks the analyst (Chongfan Liu) of the Rb-Sr isotopic compositions.

Conflicts of Interest: The authors declare no conflict of interest.

\section{References}

1. Tan, Q.P.; Xia, Y.; Xie, Z.J.; Yan, J. Migration paths and precipitation mechanisms of ore-forming fluids at the Shuiyindong Carlin-type gold deposit, Guizhou, China. Ore. Geol. Rev. 2015, 69, 140-156. [CrossRef]

2. Zheng, L.L.; Yang, R.D.; Gao, J.B.; Chen, J.; Liu, J.Z.; He, Y.N. Geochemical characteristics of the giant Nibao Carlin-type gold deposit (Guizhou, China) and their geological implications. Arab. J. Geosci. 2016, 9, 108-123. [CrossRef]

3. Hu, R.Z.; Su, W.C.; Bi, X.W.; Tu, G.C.; Hofstra, A.H. Geology and geochemistry of Carlin-type gold deposits in China. Miner. Depos. 2002, 37, 378-392.

4. Hu, R.Z.; Fu, S.L.; Huang, Y.; Zhou, M.F.; Fu, S.H.; Zhao, C.H.; Wang, Y.J.; Bi, X.W.; Xiao, J.F. The giant South China Mesozoic low-temperature metallogenic domain: Reviews and a new geodynamic model. J. Asian Earth Sci. 2017, 137, 9-34. [CrossRef]

5. Liu, J.M.; Ye, J.; Ying, H.L.; Liu, J.J.; Zheng, M.H.; Gu, X.X. Sediment-hosted micro-disseminated gold mineralization constrained by basin paleo-topographic highs in the Youjiang basin, South China. J. Asian Earth Sci. 2002, 20, 517-533. [CrossRef]

6. Peters, S.G.; Huang, J.Z.; Li, Z.P.; Jing, C.G. Sedimentary rock-hosted Au deposits of the Dian-Qian-Gui area, Guizhou and Yunnan Provinces, and Guangxi district, China. Ore. Geol. Rev. 2007, 31, 170-204. [CrossRef]

7. Zhang, Y.; Xia, Y.; Su, W.C.; Zhang, X.C.; Liu, J.Z.; Deng, Y.M. Metallogenic model and prognosis of the Shuiyindong super-large strata-bound Carlin-type gold deposit, southwestern Guizhou province, China. Chin. J. Geochem. 2010, 29, 157-166. [CrossRef]

8. Su, W.C.; Zhang, H.T.; Hu, R.Z.; Ge, X.; Xia, B.; Chen, Y.Y.; Zhu, C. Mineralogy and geochemistry of gold-bearing arsenian pyrite from the Shuiyindong Carlin-type gold deposit, Guizhou, China: Implications for gold depositional processes. Miner. Depos. 2012, 47, 653-662. [CrossRef]

9. Su, W.C.; Dong, W.D.; Zhang, X.C.; Shen, N.P.; Hu, R.Z.; Hofstra, A.H.; Cheng, L.Z. Carlin-type gold deposits in the Dian-Qian-Gui "Golden Triangle" of southwest China. Rev. Econ. Geol. 2018, 20, 157-185.

10. Cline, J.S.; Muntean, J.L.; Gu, X.X.; Xia, Y. A comparison of Carlin-type gold deposits: Guizhou province, golden triangle, southwest China, and northern Nevada, USA. Earth Sci. Front. 2013, 20, 1-18.

11. Hou, L.; Peng, H.J.; Ding, J.; Zhang, J.R.; Zhu, S.B.; Wu, S.Y.; Wu, Y.; Ouyang, H.G. Textures and in situ chemical and isotopic analyses of pyrite, Huijiabao trend, Youjiang basin, China: Implications for paragenesis and source of sulfur. Econ. Geol. 2016, 111, 331-353. [CrossRef] 
12. Xie, Z.J.; Xia, Y.; Cline, J.S.; Koenig, A.; Wei, D.T.; Tan, Q.P.; Wang, Z.P. Are there Carlin-type gold deposits in China? A comparison of the Guizhou, China, deposits with Nevada, USA, deposits. Rev. Econ. Geol. 2018, 20, 187-233.

13. Xie, Z.J.; Xia, Y.; Cline, J.S.; Pribil, M.J.; Koenig, A.; Tan, Q.P.; Wei, D.T.; Wang, Z.P.; Yan, J. Magmatic origin for sediment-hosted Au deposits, Guizhou province, China: In situ chemistry and sulfur isotope composition of pyrites, Shuiyindong and Jinfeng deposits. Econ. Geol. 2018, 113, 1627-1652.

14. Su, W.C.; Hu, R.Z.; Xia, B.; Xia, Y.; Liu, Y.P. Calcite Sm-Nd isochron age of the Shuiyindong Carlin-type gold deposit, Guizhou, China. Chem. Geol. 2009, 258, 269-274. [CrossRef]

15. Chen, M.H.; Mao, J.W.; Li, C.; Zhang, Z.Q.; Dang, Y. Re-Os isochron ages for arsenopyrite from Carlin-like gold deposits in the Yunnan-Guizhou-Guangxi "golden triangle", southwestern China. Ore. Geol. Rev. 2015, 64, 316-327. [CrossRef]

16. Chen, M.H.; Bagas, L.; Liao, X.; Zhang, Z.Q.; Li, Q.L. Hydrothermal apatite SIMS Th-Pb dating: Constraints on the timing of low-temperature hydrothermal Au deposits in Nibao, southwest China. Lithos 2019, 324, 418-428. [CrossRef]

17. Pi, Q.H.; Hu, R.Z.; Xiong, B.; Li, Q.L.; Zhong, R.C. In situ SIMS U-Pb dating of hydrothermal rutile: Reliable age for the Zhesang Carlin-type gold deposit in the golden triangle region, southwest China. Miner. Depos. 2017, 52, 1179-1190. [CrossRef]

18. Gao, W. Geochronology and Dynamics of Carlin-Type Gold Deposits in the Youjiang Basin (NW Guangxi). Ph.D. Thesis, Institute of Geochemistry, Chinese Academy of Sciences, Guiyang, China, 2018 (unpublished). (In Chinese)

19. Wang, L.; Long, C.L.; Liu, Y. Discussion on concealed rock mass delineation and gold source in southwestern Guizhou. Geoscience 2015, 29, 702-712. (In Chinese with English Abstract)

20. He, B.; Xu, Y.G.; Huang, L.X.; Luo, Z.Y.; Shi, Y.R.; Yang, Q.J.; Yu, S.Y. Age and duration of the Emeishan flood volcanism, southwest China: Geochemistry and SHRIMP zircon U-Pb dating of silicic ignimbrites, post-volcanic Xuanwei Formation and clay tuff at the Chaotian section. Earth Planet. Sci. Lett. 2007, 255, 306-323. [CrossRef]

21. Mundil, R.; Ludwig, K.R.; Metcalfe, I.; Renne, P.R. Age and timing of the Permian mass extinctions: $\mathrm{U} / \mathrm{Pb}$ dating of closed-system zircons. Science 2004, 305, 1760-1763. [CrossRef]

22. Zhou, M.F.; Zhao, J.H.; Qi, L.; Su, W.C.; Hu, R.Z. Zircon U-Pb geochronology and elemental and Sr-Nd isotope geochemistry of Permian mafic rocks in the Funing area, SW China. Contrib. Miner. Petrol. 2006, 151, 1-19. [CrossRef]

23. Yin, H.F.; Yang, F.Q.; Yu, J.X.; Peng, Y.Q.; Wang, S.Y.; Zhang, S.X. An accurately delineated Permian-Triassic boundary in continental successions. Sci. China: Earth Sci. 2007, 35, 1281-1292. [CrossRef]

24. Shepherd, T.J.; Darbyshire, D.P.F. Fluid inclusion Rb-Sr isochrons for dating mineral deposits. Nature 1981, 290, 578-579. [CrossRef]

25. Norman, D.I.; Lands, G.P. Source of mineralizing components in hydrothermal ore fluids as evidenced by ${ }^{87} \mathrm{Sr} /{ }^{86} \mathrm{Sr}$ and stable isotope data from the Pasto Bueno deposit, Peru. Econ Geol. 1983, 78, 451-465. [CrossRef]

26. Rossman, G.R.; Weis, D.; Wasserburg, G.J. Rb, Sr, Nd and Sm concentrations in quartz. Geochim. Cosmochim. Acta 1987, 51, 2325-2329. [CrossRef]

27. Changkakoti, A.; Gray, J.; Krsticl, D.; Cumming, G.L.; Morton, R.D. Determination of radiogenic isotope $(\mathrm{Rb} / \mathrm{Sr}, \mathrm{Sm} / \mathrm{Nd}$, and $\mathrm{Pb} / \mathrm{Pb})$ in fluid inclusion water: An example from the Bluebell $\mathrm{Pb}-\mathrm{Zn}$ deposit, British Columbia, Canada. Geochimi. Cosmochim. Acta 1988, 52, 961-967. [CrossRef]

28. Li, H.Q.; Liu, J.Q.; Wei, L. The Chronological and Geological Application of Fluid Inclusions in Hydrothermal Deposits; Geological Publishing House: Beijing, China, 1993; pp. 1-25. (In Chinese)

29. Mo, C.H.; Wang, X.Z.; Cheng, J.P. Auriferous quartz veins from the Dongping gold deposit, NW Hebei province and metallogenesis-Fluid inclusion Rb-Sr isochron evidence. Chin. J. Geochem. 1996, 15, $265-271$.

30. Zhang, L.C.; Shen, Y.C.; Ji, J.S. Characteristics and genesis of Kanggur gold deposit in the eastern Tianshan mountains, NW China: Evidence from geology, isotope distribution and chronology. Ore Geol. Rev. 2003, 23, 71-90. [CrossRef]

31. Zhu, Y.F.; Zhou, J.; Zeng, Y.S. The Tianger (Bingdaban) shear zone hosted gold deposit, west Tianshan, NW China: Petrographic and geochemical characteristics. Ore Geol. Rev. 2007, 32, 337-365. [CrossRef] 
32. Ni, P.; Wang, G.G.; Chen, H.; Xu, Y.F.; Guan, S.J.; Pan, J.Y.; Li, L. An Early Paleozoic orogenic gold belt along the Jiang-Shao Fault, south China: Evidence from fluid inclusions and $\mathrm{Rb}-\mathrm{Sr}$ dating of quartz in the Huangshan and Pingshui deposits. J. Asian Earth Sci. 2015, 103, 87-102. [CrossRef]

33. Sahoo, A.K.; Krishnamurthi, R.; Vadlamani, R.; Pruseth, K.L.; Narayanan, M.; Varghese, S.; Pradeepkumar, T. Geneticpects of gold mineralization in the southern Granulite Terrain, India. Ore Geol. Rev. 2016, 72, 1243-1262. [CrossRef]

34. Mao, J.W.; Xie, G.Q.; Li, X.F.; Zhang, C.Q.; Mei, Y.X. Mesozoic large scale mineralization and multiple lithospheric extension in south China. Earth Sci. Front. 2004, 11, 45-55. (In Chinese with English Abstract)

35. Zhang, F.; Yang, K.Y. Metallogenic geochronology for the micro-grain disseminated gold deposits in southwestern Guizhou province. Chin. Sci. Bull. 1992, 27, 1593-1595. (In Chinese with English Abstract)

36. Chen, M.H.; Zhang, Y.; Meng, Y.Y.; Lu, G.; Liu, S.Q. The confirmation of the upper limit of metallogenetic epoch of Liaotun gold deposit in western Guangxi, China, and its implicationon chronology of Carlin-type gold deposits in Yunnan-Guizhou-Guangxi "golden triangle" area. Miner. Depos. 2014, 33, 1-13. (In Chinese with English Abstract)

37. Su, W.C.; Yang, K.Y.; Hu, R.Z.; Chen, F. Fluid inclusion chronological study of the Carlin-type gold deposits in southwestern China: As exemplified by the Lannigou gold deposit, Guizhou Province. Acta Mineral. Sin. 1998, 18, 359-362. (In Chinese with English Abstract)

38. Wang, Z.P. Genesis and dynamic mechanism of the epithermal ore deposits, SW Guizhou, China-A Case Study of Gold and Antimony Deposits. Ph.D. Thesis, Institute of Geochemistry, Chinese Academy of Sciences, Guiyang, China, 2013. (In Chinese)

39. Chen, B.J. Ore-Forming Mechanism and Background of Continental Dynamics of the Shuiyindong Carlin-Type Gold Deposit, Southwestern Guizhou, China. Ph.D. Thesis, Chengdu University of Technology, Chengdu, China, 2010. (In Chinese)

40. Peng, J.T.; Hu, R.Z.; Jiang, G.H. Strontium-neodymium isotope system of fluorites from the Qinglong antimony deposit, Guizhou Province: Constrains on the mineralizing age and ore-forming materials sources. Acta Petrol. Sin. 2003, 19, 785-791. (In Chinese with English Abstract)

41. Xiao, X.G. Geochronology, Ore Geochemistry and Genesis of the Banpo Antimony Deposit, Guizhou Province, China. Ph.D. Thesis, Kunming University of Seience and Technology, Kunming, China, 2014. (In Chinese)

42. Wang, J.S. Mineralization, Geochronology and Geodynamics of the Low-Temperature Epithermal Metallogenic Domain in Southwestern China. Ph.D. Thesis, Institute of Geochemistry, Chinese Academy of Sciences, Guiyang, China, 2012. (In Chinese)

43. Hu, R.Z.; Su, W.C.; Bi, X.W.; Li, Z.Q. A possible evolution way of ore-forming hydrothermal fluid for the Carlin-type gold deposits in the Yunnan-Guizhou-Guanxi triangle area. Acta Mineral. Sini. 1995, 15, 144-149. (In Chinese with English Abstract)

44. Bureau of Geology and Mineral Resources of Guizhou Province. Guizhou Regional Geology; Geological Publishing House: Beijing, China, 1987; pp. 1-698. (In Chinese)

45. Li, W.; Huang, Z.; Yin, M. Isotope geochemistry of the Huize Zn-Pb ore field, Yunnan Province, Southwestern China: Implication for the sources of ore fluid and metals. Geochem. J. 2007, 41, 65-81. [CrossRef]

46. Palmer, M.R.; Elderfield, H. Sr isotope composition of sea water over the past 75 Myr. Nature 1985, 314, 526-528. [CrossRef]

47. Faure, G. Principles of Isotope Geology, 2nd ed; Wiley: New York, NY, USA, 1986; pp. 1-589.

48. Chen, J.; Yang, R.D.; Du, L.J.; Zheng, L.L.; Gao, J.B.; Lai, C.K.; Wei, H.R.; Yuan, M.G. Mineralogy, geochemistry and fluid inclusions of the Qinglong $\mathrm{Sb}-(\mathrm{Au})$ deposit, Youjiang basin (Guizhou, SW China). Ore Geol. Rev. 2018, 92, 1-18. [CrossRef]

(C) 2019 by the authors. Licensee MDPI, Basel, Switzerland. This article is an open access article distributed under the terms and conditions of the Creative Commons Attribution (CC BY) license (http://creativecommons.org/licenses/by/4.0/). 